Article

\title{
Enhanced Photocatalytic Hydrogen Production of the Polyoxoniobate Modified with RGO and PPy
}

\author{
Shiliang Heng ${ }^{1}$, Lei Li ${ }^{1,2}$, Weiwei Li ${ }^{1}$, Haiyan Li $^{1}$, Jingyu Pang ${ }^{1}$, Mengzhen Zhang ${ }^{1}$, Yan Bai ${ }^{1}$,* \\ and Dongbin Dang ${ }^{1, *}$ \\ 1 Henan Key Laboratory of Polyoxometalate Chemistry, College of Chemistry and Chemical Engineering, \\ Henan University, Kaifeng 475004, China; 104753170767@vip.henu.edu.cn (S.H.); leili1202@126.com (L.L.); \\ 104753160776@vip.henu.edu.cn (W.L.); lihaiyan@henu.edu.cn (H.L.); pjy@henu.edu.cn (J.P.); \\ 104754181031@vip.henu.edu.cn (M.Z.) \\ 2 College of Chemistry and Chemical Engineering, Anyang Normal University, Anyang 455002, China \\ * Correspondence: baiyan@henu.edu.cn (Y.B.); dangdb@henu.edu.cn (D.D.)
}

Received: 27 October 2020; Accepted: 2 December 2020; Published: 7 December 2020

check for updates

\begin{abstract}
The development of high-efficiency, recyclable, and inexpensive photocatalysts for water splitting for hydrogen production is of great significance to the application of solar energy. Herein, a series of graphene-decorated polyoxoniobate photocatalysts $\mathrm{Nb}_{6} / \mathrm{PPy}-\mathrm{RGO}\left(\mathrm{Nb}_{6}=\mathrm{K}_{7} \mathrm{HNb}_{6} \mathrm{O}_{19}\right.$, $\mathrm{RGO}=$ reduced graphene oxide, $\mathrm{PPy}=$ polypyrrole), with the bridging effect of polypyrrole were prepared through a simple one-step solvothermal method, which is the first example of polyoxoniobate-graphene-based nanocomposites. The as-fabricated photocatalyst showed a photocatalytic $\mathrm{H}_{2}$ evolution activity without any co-catalyst. The rate of $1038 \mu \mathrm{mol} \mathrm{g}{ }^{-1}$ in $5 \mathrm{~h}$ under optimal condition is almost 43 times higher than that of pure $\mathrm{K}_{7} \mathrm{HNb}_{6} \mathrm{O}_{19} \cdot 13 \mathrm{H}_{2} \mathrm{O}$. The influencing factors for photocatalysts in photocatalytic hydrogen production under simulated sunlight were studied in detail and the feasible mechanism is presented in this paper. These results demonstrate that $\mathrm{Nb}_{6} \mathrm{O}_{19}$ acts as the main catalyst and electron donor, RGO provides active sites, and PPy acted as an electronic bridge to extend the lifetime of photo-generated carriers, which are crucial factors for photocatalytic $\mathrm{H}_{2}$ production.
\end{abstract}

Keywords: polyoxoniobate; $\mathrm{Nb}_{6} / \mathrm{PPy}-\mathrm{RGO}$ composites; electronic bridge; $\mathrm{H}_{2}$ production

\section{Introduction}

With the widespread energy consumption and environmental problems, it is necessary and urgent to search for sources of green and clean energy to replace traditional fossil fuels [1-4]. Since the first discovery of photoelectrochemical water splitting into $\mathrm{H}_{2}$ via the semiconductor $\mathrm{TiO}_{2}$ by Fujishima and Honda in 1972, photocatalytic water splitting to hydrogen production has long been viewed as a promising and attractive strategy [5]. In recent years, many semiconductor materials have been reported for photocatalytic hydrogen evolution, in which the band gap, the position of the conduction band, the separation of electrons and holes and the lifetime of carriers are the key factors affecting photocatalysis [6,7]. Nonetheless, the exploitation of highly effective semiconductor materials for photocatalytic hydrogen evolution is still in the infant stage [8-10].

Polyoxometalates (POMs) have been applied in photocatalytic $\mathrm{H}_{2}$ or $\mathrm{O}_{2}$ evolution and the photodegradation of organic dyes [11-16], due to their controllable and stable structures, superior redox and semiconductor properties [17-22]. However, the lower $\mathrm{H}_{2}$ production rates and the introduction of the scarce noble metal have largely limited the scale of their potential applications. It is a feasible strategy to design and prepare photocatalyst composites based on POMs, such as $\left[\mathrm{PW}_{12} \mathrm{O}_{40}\right]^{3-}$, $\left[\mathrm{PMo}_{12} \mathrm{O}_{40}\right]^{3-},\left[\mathrm{SiW}_{12} \mathrm{O}_{40}\right]^{4-}$ and $\left[\mathrm{PMo}_{10} \mathrm{~V}_{2} \mathrm{O}_{40}\right]^{5-}$ [23-30]. In 2018, Zhang reported an interesting 
investigation on the preparation of a novel $\mathrm{Ag}_{3} \mathrm{PO}_{4} / \mathrm{POM} /$ graphene oxide (GO) heterostructure photocatalyst based on molybdophosphoric acid, which has excellent photocatalytic activity for photodegraded rhodamine $\mathrm{B}$ and water splitting for $\mathrm{H}_{2}$ evolution, because of its increased surface area, electronegativity and structural stability [28]. This is a pioneering work in the study of photocatalyst composites from well conductive graphene and $\mathrm{POMs}$ for $\mathrm{H}_{2}$ production.

Graphene is an ideal support material and as a solid electron mediator in photocatalysis, owing to the special 2D sp 2 -hybridied honeycomb structure [2,31], high charge carrier mobility (ca. 10,000 $\mathrm{cm}^{2} \mathrm{~V}^{-1} \mathrm{~s}^{-1}$ ) and large theoretical surface area $\left(2600 \mathrm{~m}^{2} \mathrm{~g}^{-1}\right)$ [32-34]. Therefore, the combination of graphene with semiconductors can not only inhibit the recombination of the photogenerated electron-hole pairs, but also adjust the band gap of photocatalysts and provide more photoactive sites [35-37]. More importantly, functionalization of $\mathrm{N}$-doped graphene is a good way to improve the photocatalytic behavior. In particular, pyrrole-N-doped graphene is used as an oxygen-reduction active site to accelerate the interface-catalytic process [38]. Therefore, it is a promising work to introduce pyrrole into POM and graphene-based composites for photocatalytic decomposition of water into $\mathrm{H}_{2} \mathrm{O}_{2}$ or hydrogen and oxygen.

As an important kind of POMs, polyoxoniobates have been widely used in photocatalytic $\mathrm{H}_{2}$ evolution due to higher negative charges and stronger basicity of $\left[\mathrm{Nb}_{6} \mathrm{O}_{19}\right]^{8-}$, which can easily accept electrons and keep an intact structure. Recently, several studies on photocatalytic $\mathrm{H}_{2}$ evolution by polyoxoniobates have been reported, in which precious metals are essential components as co-catalysts [39-43]. Taking these studies into account, we hope to design a new type of POM-based composite photocatalysts with good photocatalytic $\mathrm{H}_{2}$ production performance without any co-catalyst. Therefore, graphene was introduced into $\left[\mathrm{Nb}_{6} \mathrm{O}_{19}\right]^{8-}$ for the first time to produce composite photocatalysts, where it could act as the active sites to produce $\mathrm{H}_{2}$, avoiding the use of the scarce noble metal, while using economical and non-toxic pyrrole as a bridging material to prolong the lifetime of photo-generated carriers [44,45], decreasing the recombination of electron-hole pairs. Herein, $\mathrm{Nb}_{6} / \mathrm{PPy}-\mathrm{RGO}\left(\mathrm{Nb}_{6}=\mathrm{K}_{7} \mathrm{HNb}_{6} \mathrm{O}_{19}, \mathrm{RGO}=\right.$ reduced graphene oxide, $\mathrm{PPy}=$ polypyrrole $)$, composites with the appearance of peony flowers were prepared using a simple one-pot solvothermal process. By adjusting the molar rate of $\mathrm{Nb}_{6}$, the volume of pyrrole and solvothermal temperature, a series of $\mathrm{Nb}_{6} / \mathrm{PPy}-\mathrm{RGO}$ nanocomposites were obtained. Among the achieved $\mathrm{Nb}_{6} / \mathrm{PPy}-\mathrm{RGO}$ composites, $\mathrm{Nb}_{6} / \mathrm{PPy}-\mathrm{RGO}-0.25$ shows an outstanding photocatalytic activity with $\mathrm{H}_{2}$ production rate of $1038 \mu \mathrm{mol} \mathrm{g}^{-1}$ in $5 \mathrm{~h}$ under the simulated sunlight without co-catalyst. Moreover, as-obtained $\mathrm{Nb}_{6} /$ PPy-RGO composites demonstrate high stability and superb recyclability, which can be attributed to the collaborations among $\mathrm{Nb}_{6}, \mathrm{RGO}$ and PPy.

\section{Materials and Methods}

\subsection{Materials}

All the reagents and solvents used in this experiment were reagent grade and were used without further treatment. Graphite powder, sulfuric acid $\left(\mathrm{H}_{2} \mathrm{SO}_{4}, 98 \%\right)$, sodium sulfate $\left(\mathrm{Na}_{2} \mathrm{SO}_{4}, 99 \%\right)$, sodium nitrate $\left(\mathrm{NaNO}_{3}, 99 \%\right)$, potassium permanganate $\left(\mathrm{KMnO}_{4}, 99.5 \%\right)$ and pyrrole $\left(\mathrm{C}_{4} \mathrm{H}_{5} \mathrm{~N}, 98 \%\right)$ were purchased from Aladdin Biochemical Technology Co. (Shanghai, China). The $\mathrm{K}_{7} \mathrm{HNb}_{6} \mathrm{O}_{19} \cdot 13 \mathrm{H}_{2} \mathrm{O}$ was synthesized according to the method in the literature [46], and its purity was determined by infrared spectra (IR). Graphene oxide (GO) was manufactured by a modified Hummers' method and the purity of GO was confirmed by X-ray diffraction (XRD) [47,48].

\subsection{Synthesis of $\mathrm{Nb}_{6} / \mathrm{PPy}-\mathrm{RGO}$}

As shown in Scheme 1, $4 \mathrm{mg}$ graphene oxide (GO) was added to $2 \mathrm{~mL}$ distilled water in a $25 \mathrm{~mL}$ Teflon lining and ultrasonic for $1 \mathrm{~h}$. Then, a solution containing $110 \mu \mathrm{L}$ pyrrole (denoted as Py) and $1 \mathrm{~mL}$ ethanol was added to the above solution., After stirring for $30 \mathrm{~min}, \mathrm{Nb}_{6}$ ( $345 \mathrm{mg}, 0.25 \mathrm{mmol}$ ) was added to the mixed solution and heated at $180{ }^{\circ} \mathrm{C}$ for $12 \mathrm{~h}$. After cooling to room temperature, the achieved product, $\mathrm{Nb}_{6} / \mathrm{PPy}-\mathrm{RGO}-0.25$, was respectively washed with deionized water four times 
and ethanol two times to remove the excess reactants, and finally dried at $60{ }^{\circ} \mathrm{C}$ under vacuum for $12 \mathrm{~h}$. According to the same procedure, except for the amount of $\mathrm{Nb}_{6}(173 \mathrm{mg}, 0.125 \mathrm{mmol})$ and (523 mg, $0.375 \mathrm{mmol}$ ), the samples $\mathrm{Nb}_{6} / \mathrm{PPy}-\mathrm{RGO}-0.125$ and $\mathrm{Nb}_{6} / \mathrm{PPy}-\mathrm{RGO}-0.375$ were respectively obtained. Similarly, to gain further insight into the effect of the amount of $\mathrm{Nb}_{6}$ and reaction temperature on the photocatalytic activity of the catalysts, controlling the amount of $\mathrm{Nb}_{6}(0.25 \mathrm{mmol})$, GO and temperature, we achieved $\mathrm{Nb}_{6} / \mathrm{PPy}-\mathrm{RGO}-90$ and $\mathrm{Nb}_{6} / \mathrm{PPy}-\mathrm{RGO}-130$ by adjusting the amount of pyrrole (90 and $130 \mu \mathrm{L})$. Simultaneously, controlling the amount of $\mathrm{Nb}_{6}(0.25 \mathrm{mmol}), \mathrm{GO}$ and pyrrole $(110 \mu \mathrm{L})$, the samples $\mathrm{Nb}_{6} / \mathrm{PPy}-\mathrm{RGO}-160{ }^{\circ} \mathrm{C}$ and $\mathrm{Nb}_{6} / \mathrm{PPy}-\mathrm{RGO}-190{ }^{\circ} \mathrm{C}$ were fabricated. As a comparison, the PPy-RGO was also obtained without the addition of $\mathrm{Nb}_{6}$.

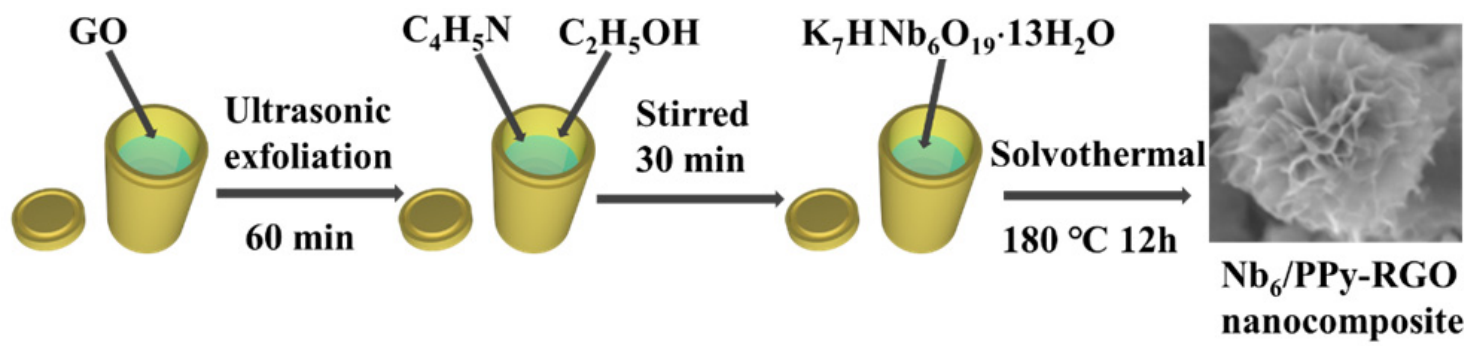

Scheme 1. Illustration of the synthesis process of $\mathrm{Nb}_{6} / \mathrm{PPy}-\mathrm{RGO}$ composites $\left(\mathrm{K}_{7} \mathrm{HNb}_{6} \mathrm{O}_{19} \cdot 13 \mathrm{H}_{2} \mathrm{O}=\right.$ $\mathrm{Nb}_{6}, \mathrm{RGO}=$ reduced graphene oxide, $\mathrm{PPy}=$ polypyrrole).

\subsection{Characterization}

The morphology and microstructure of the synthetic samples were characterized using a field emission scanning electron microscopy (FESEM, JSM-7610F, Electronics Co., LTD., Tokyo, Japan) at $10 \mathrm{kV}$ and a transmission electron microscopy (TEM, JEM-2100F, Electronics Co., LTD., Tokyo, Japan) at $200 \mathrm{kV}$ ). Powder X-ray diffraction (XRD, Bruker optics Instruments company, Karlsruhe, Germany) was measured from $5^{\circ}$ to $80^{\circ}$ at room temperature on a Bruker D8 Advance diffractometer with $\mathrm{Cu}-\mathrm{K} \alpha$ radiation and the Fourier transform-infrared spectra (FT-IR, KBr pellets, Bruker optics Instruments company, Karlsruhe, Germany) were recorded on a Nicolet 170 SXFT-IR spectrophotometer ranging from 4000 to $500 \mathrm{~cm}^{-1}$. X-ray photoelectron spectroscopy (XPS, Thermo Fisher Scientific, Waltham, MA, USA) was recorded on an ESCALAB 250Xi X-ray photoelectron spectrometer with an $\mathrm{Al}-\mathrm{K} \alpha(h v=1486.6 \mathrm{eV})$ monochromatic radiation source. The binding energy peak position of each sample was calibrated by the C 1 s peak at $284.8 \mathrm{eV}$. UV-visible spectra were achieved on a Shimadzu UV-2600 UV/Vis spectrophotometer (Shimadzu Instrument Co., LTD, Kyoto-fu, Japan) using BaSO as a reference. Raman spectroscopy (Renishaw company, London, UK) was prepared using a Renishaw in Via Raman spectrometer with excitation by $325 \mathrm{~nm}$ Photoluminescence (PL) spectra were obtained at excitation wavelength $385 \mathrm{~nm}$ with TU-1900 (PuXi Company, Beijing, China).

\subsection{Photocatalytic Hydrogen Production}

Photocatalytic hydrogen producing experiments were performed using a method similar to the literature [6]. Photocatalyst $(50 \mathrm{mg})$ was added to a solution of deionized water $(40.0 \mathrm{~mL})$ and $\mathrm{CH}_{3} \mathrm{OH}(10.0 \mathrm{~mL}, \mathrm{pH}=7)$ in a quartz vessel. The reaction system was irradiated by a $300 \mathrm{~W}$ Xe lamp (Perfect light PLS-SXE300, Perfectlight Technology Co., Ltd, Beijing, China), and the temperature was maintained at about $5{ }^{\circ} \mathrm{C}$. The product $\mathrm{H}_{2}$ was measured by gas chromatograph (FL-9790) on line. After each photocatalytic test, photocatalysts were collected by centrifugation without reactivated before each cycle, washed with $\mathrm{H}_{2} \mathrm{O}$ and $\mathrm{C}_{2} \mathrm{H}_{5} \mathrm{OH}$ to remove impurities, then used after drying.

\subsection{Photocatalytic Measurement}

The Mott-Schottky curves were tested on an AMETEK Princeton Applied Research (Versa STAT 4, Princeton, NJ, USA) electrochemical workstation (FTO = fluorine-doped tin oxide substrate, $1 \mathrm{~cm} \times 1.5 \mathrm{~cm}$ ). The electrochemical impedance spectroscopy (EIS) and photocurrent response 
were recorded on an electrochemical workstation (CHI660, Chenhua, Shanghai, China) equipped with a three-electrode system with a complex/FTO as the working electrode, platinum foil as the counter electrode and $\mathrm{Ag} / \mathrm{AgCl}$ as the reference electrode in $0.2 \mathrm{M}$ sodium sulfate solution $\left(\mathrm{Na}_{2} \mathrm{SO}_{4}\right)$. The working electrode complex/FTO was prepared by dropwise adding $50 \mu \mathrm{L}$ of sample suspensions containing $\mathrm{Nb}_{6} / \mathrm{PPy}-\mathrm{RGO}$ composites $(3.0 \mathrm{mg})$, ethanol $(1.0 \mathrm{~mL})$, and nafion $(20 \mu \mathrm{L})$ onto a FTO substrate $(1 \mathrm{~cm} \times 1.5 \mathrm{~cm})$.

\section{Results and Discussion}

\subsection{Structural Characterizations}

The XRD patterns of $\mathrm{GO}, \mathrm{Nb}_{6}$, and $\mathrm{Nb}_{6} / \mathrm{PPy}-\mathrm{RGO}$ composites were investigated. As shown in Figure 1 and Figure S1, pristine GO and RGO show a single peak near $12^{\circ}$ and $26^{\circ}$, respectively, while pristine $\mathrm{K}_{7} \mathrm{HNb}_{6} \mathrm{O}_{19}$ has sharp diffraction peaks at $9.7^{\circ}, 26^{\circ}$ and $48^{\circ}$, respectively, which is consistent with the literature reports [46-48]. The broad peaks centered on $27.5^{\circ}$ of $\mathrm{Nb}_{6} / \mathrm{PPy}-\mathrm{RGO}$ composites can be attributed to the combined action of PPy and RGO, while the characteristic peaks at $46^{\circ}$ are attributed to the superposition of $\mathrm{Nb}_{6}$ and PPy [49-51]. In $\mathrm{Nb}_{6} / \mathrm{PPy}-\mathrm{RGO}$ composite materials, although it is not obvious in $\mathrm{Nb}_{6} / \mathrm{PPy}-\mathrm{RGO}-0.325$ and $\mathrm{Nb}_{6} / \mathrm{PPy}-\mathrm{RGO}-0.25$, the characteristic peaks of raw materials can still be found. No additional diffraction peaks were observed, confirming the formation of the $\mathrm{Nb}_{6} / \mathrm{PPy}$-RGO composites. The crystallite sizes of the catalysts calculated from the XRD patterns were shown in Table 1.

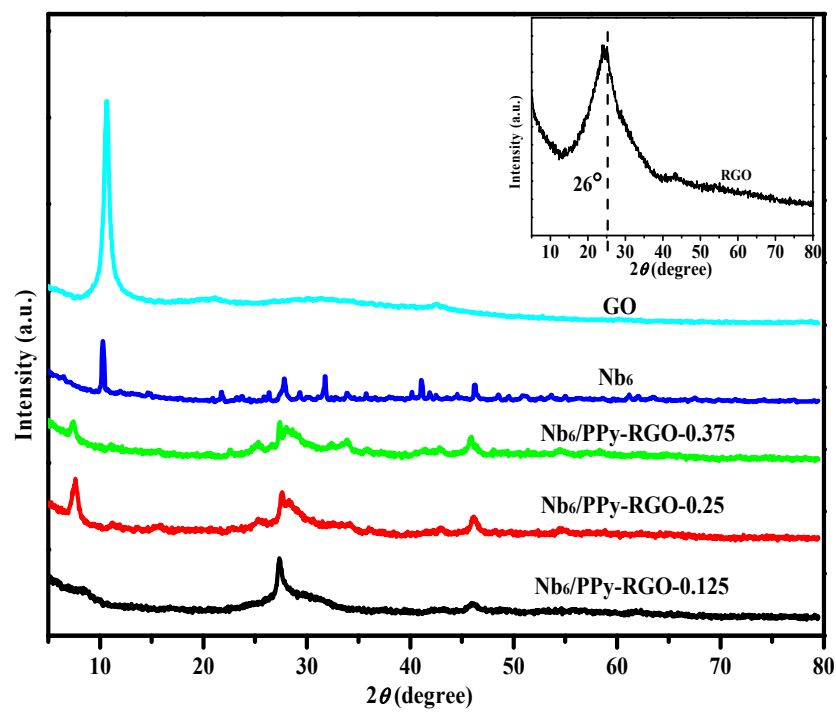

Figure 1. X-ray diffraction (XRD) patterns of graphene oxide (GO), $\mathrm{RGO}$ (insert figure), $\mathrm{Nb}_{6}$ and $\mathrm{Nb}_{6} /$ PPy-RGO composites.

Table 1. The crystallite sizes of $\mathrm{Nb}_{6}$ and $\mathrm{Nb}_{6} / \mathrm{PPy}-\mathrm{RGO}$ composites $\left(\mathrm{Nb}_{6}=\mathrm{K}_{7} \mathrm{HNb}_{6} \mathrm{O}_{19}, \mathrm{RGO}=\right.$ reduced graphene oxide, $\mathrm{PPy}=$ polypyrrole).

\begin{tabular}{ccccc}
\hline Samples & $\mathrm{Nb}_{6}$ & $\mathrm{Nb}_{6} /$ PPy-RGO-0.125 & $\mathrm{Nb}_{6} /$ PPy-RGO-0.25 & $\mathrm{Nb}_{6} /$ PPy-RGO-0.375 \\
\hline Crystalite sizes $(\mathrm{nm})$ & 26 & 6 & 12 & 14 \\
\hline
\end{tabular}

The structure of $\mathrm{Nb}_{6} / \mathrm{PPy}$-RGO-0.25 composite has also been evidenced by Fourier transform-infrared (FT-IR) spectroscopy (Figure 2). The peak at $1398 \mathrm{~cm}^{-1}$ is assigned to the C-O stretching vibration due to $\pi-\pi$ interaction between PPy and RGO. The peak at $1637 \mathrm{~cm}^{-1}$ is assigned to $\mathrm{H}-\mathrm{O}-\mathrm{H}$ stretching vibration and the peak at $1258 \mathrm{~cm}^{-1}$ was assigned to $\mathrm{C}-\mathrm{H}$ and $\mathrm{C}-\mathrm{N}$ in-plane deformation vibration, further implying the combination of GO with PPy [52,53]. The characteristic peaks at 840 and $887 \mathrm{~cm}^{-1}$ could be attributed to the terminal $\mathrm{Nb}-\mathrm{O}$ stretching vibration, and the peaks 
appearing at 532 and $597 \mathrm{~cm}^{-1}$ correspond to $\mathrm{Nb}-\mathrm{O}-\mathrm{Nb}$ bonds [54]. The result shows that $\mathrm{Nb}_{6} \mathrm{was}$ successfully inserted into the final composite.

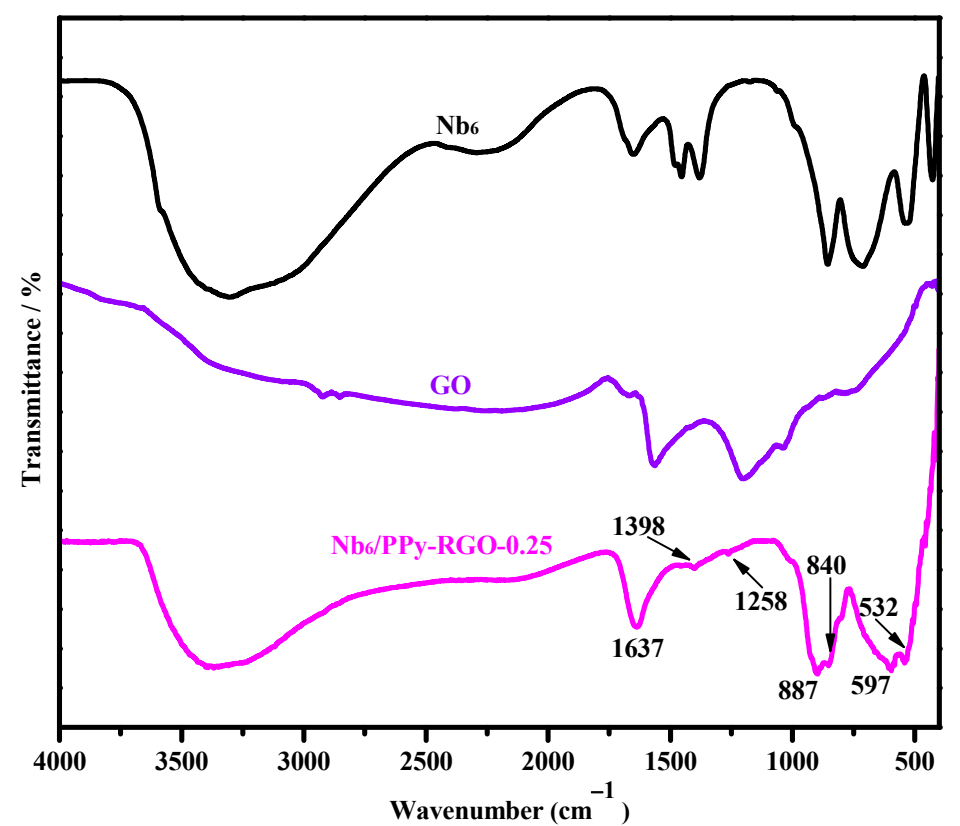

Figure 2. Fourier transform-infrared (FT-IR) spectra of $\mathrm{Nb}_{6}$, GO and $\mathrm{Nb}_{6} / \mathrm{PPy}-\mathrm{RGO}-0.25$.

From the Raman spectra shown in Figure 3, the higher wavenumber bands at 1334 and $1584 \mathrm{~cm}^{-1}$ are ascribed to $\mathrm{D}$ band and $\mathrm{G}$ band of GO. It is worth noting that the peak intensity ratio $\left(I_{\mathrm{D}} / I_{\mathrm{G}}\right)$ is a popular method to evaluate the disorder and reduction of graphene materials. The $I_{\mathrm{D}} / I_{\mathrm{G}}$ ratio of the pure GO is about 0.76 , while that of the $\mathrm{Nb}_{6} / \mathrm{PPy}-\mathrm{RGO}-0.25$ composite is about 0.99 . The numeric addition indicated that the oxygen-containing functional groups were partially reduced, meaning the transition of GO to RGO in the process of solvothermal reaction [54]. Compared with the characteristic peaks of $\mathrm{Nb}_{6}\left(541,827\right.$ and $\left.875 \mathrm{~cm}^{-1}\right)$ [55,56], the redshift could be found for $\mathrm{Nb}_{6} / \mathrm{PPy}-\mathrm{RGO}-0.25$ (878 and $620 \mathrm{~cm}^{-1}$ ), which may be assigned to the strong interaction among the $\mathrm{Nb}_{6}, \mathrm{PPy}$, and RGO of the composites.

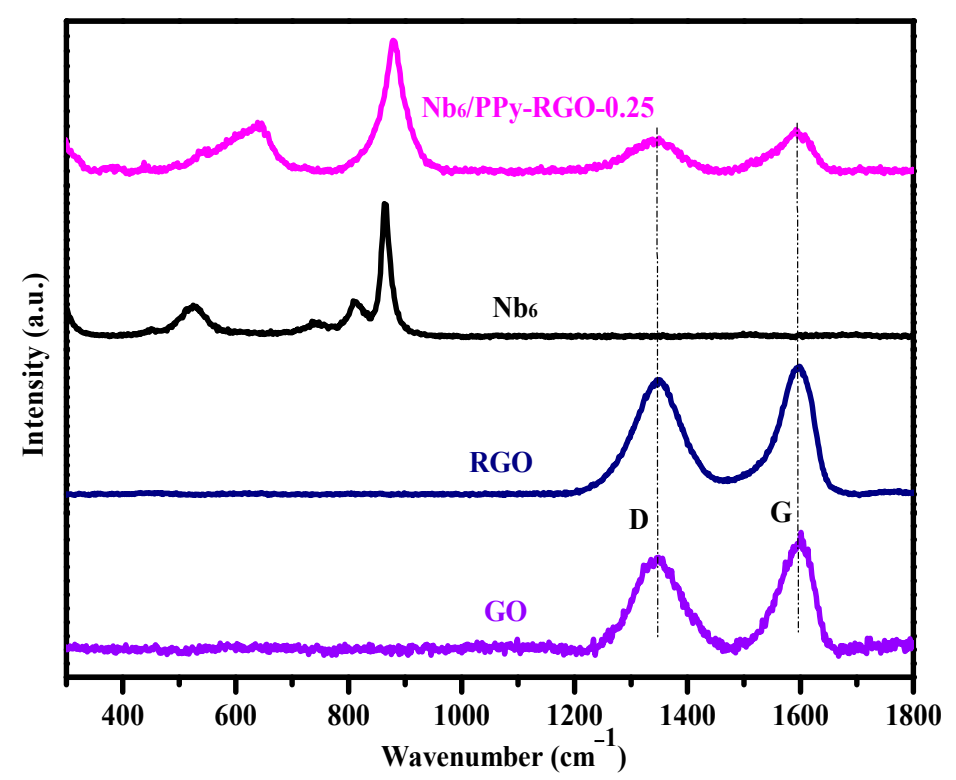

Figure 3. Raman spectra of $\mathrm{Nb}_{6}, \mathrm{GO}, \mathrm{RGO}$ and $\mathrm{Nb}_{6} / \mathrm{PPy}-\mathrm{RGO}-0.25$. 
In order to further identify the structure of composites, the XPS spectra were tested for $\mathrm{Nb}_{6} /$ PPy-RGO-0.25 composites and GO, as well as $\mathrm{Nb}_{6}$ (Figure 4). As shown in Figure $4 \mathrm{~A}$, the full spectrum clearly shows the presence of $\mathrm{C}, \mathrm{O}, \mathrm{N}, \mathrm{K}$, and $\mathrm{Nb}$ elements in the composite sample, which is consistent with the chemical composition of the photocatalyst. As shown in Figure $4 \mathrm{~B}$, the binding energies of C 1s, including 284.05, 285.60, 286.47 and $288.37 \mathrm{eV}$, could be attributed to carbon of the non-oxygenated ring, $\mathrm{C}-\mathrm{OH}, \mathrm{C}-\mathrm{O}$ and $\mathrm{C}=\mathrm{O}$ in $\mathrm{Nb}_{6} / \mathrm{PPy}-\mathrm{RGO}-0.25$, respectively, which are lower and weaker than that of pure GO $(284.74,285.97,287.07$ and $289.08 \mathrm{eV})$. These results demonstrate that the GO has been successfully reduced in composites, which is in agreement with Raman spectra [57-60]. For pure GO, the XPS of $\mathrm{O} 1 \mathrm{~s}$ contains two peaks at 532.20 and $533.08 \mathrm{eV}$ assigned to $\mathrm{C}=\mathrm{O} / \mathrm{C}-\mathrm{O}$ and $\mathrm{O}-\mathrm{C}=\mathrm{O}$, respectively. The peaks at $531.96,529.05$, and $530.63 \mathrm{eV}$ in the pure $\mathrm{Nb}_{6}$ sample belong to $\mathrm{Nb}-\mathrm{O}-\mathrm{Nb}, \mathrm{Nb}-\mathrm{O}-\mathrm{H}$, and crystal water, respectively. There are two main peaks at 529.73 and $531.74 \mathrm{eV}$ in $\mathrm{Nb}_{6} / \mathrm{PPy}-\mathrm{RGO}-0.25$, which can be attributed to binding energies of $\mathrm{O}$ 1s in $\mathrm{Nb}-\mathrm{O}-\mathrm{Nb}$ and $\mathrm{Nb}-\mathrm{O}-\mathrm{H}$ (Figure 4C [61]. Figure 4D illustrates a comprehensive $\mathrm{Nb} 3 \mathrm{~d}$ XPS analysis of the Nb$/ \mathrm{PPy}_{6}-\mathrm{RGO}-0.25$ and $\mathrm{Nb}_{6}$. The binding energies of 206.49 and $209.26 \mathrm{eV}$ could be assigned to $\mathrm{Nb} 3 \mathrm{~d}_{5 / 2}$ and $\mathrm{Nb} 3 \mathrm{~d}_{3 / 2}$ of $\mathrm{Nb}^{5+}$ (highest oxidation state) in $\mathrm{Nb}_{6} / \mathrm{PPy}-\mathrm{RGO}-0.25$. Compared with $\mathrm{Nb}_{6}$, the peaks of $\mathrm{Nb} 3 \mathrm{~d}$ shifted to higher binding energy by $\sim 1 \mathrm{eV}$, which may be caused by electron transfer from $\mathrm{Nb}_{6}$ to $\mathrm{RGO}_{\text {in }}$ composites [54]. As shown in Figure 4E, the N 1s peaks centered at 398.01 and $399.55 \mathrm{eV}$ are vested to the pyridinic and pyrrolic of $\mathrm{N}$ atom in polymer. In addition, there is a weak peak at the center of $394.11 \mathrm{eV}$, corresponding to the $\mathrm{Nb}-\mathrm{N}$ bond, indicating the formation of chemical bonds between PPy and $\mathrm{Nb}_{6}[62]$.
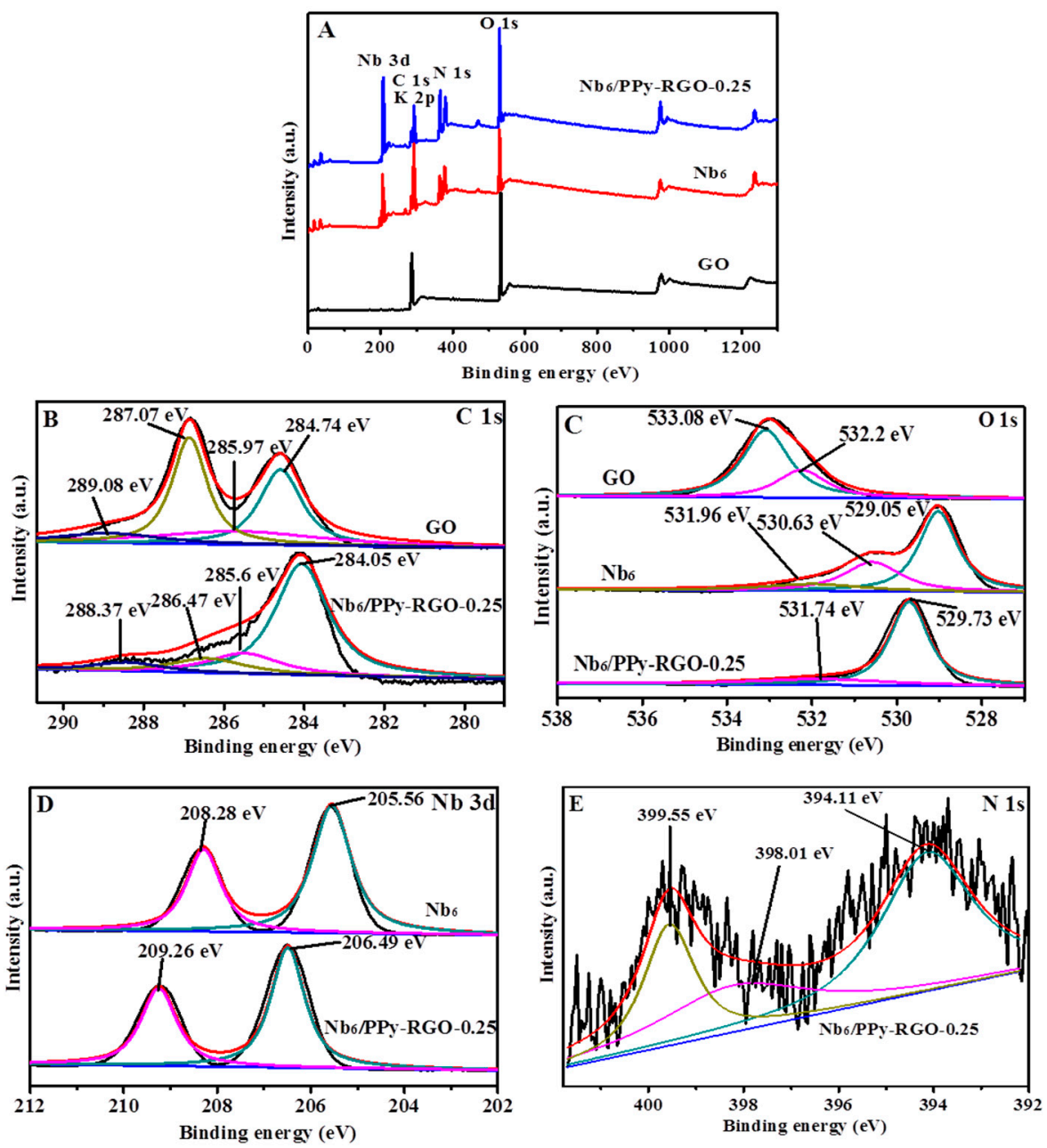

Figure 4. X-ray photoelectron spectroscopy (XPS) of $\mathrm{GO}, \mathrm{Nb}_{6}$, and $\mathrm{Nb}_{6} / \mathrm{PPy}-\mathrm{RGO}-0.25$, (A) survey; (B) C 1s; (C) O 1s; (D) Nb 3d; (E) N 1s. 


\subsection{Nanosphere Morphologies}

As shown in Figure 5, the results show that the morphology of $\mathrm{Nb}_{6}$ is rodlike. However, when fabricated with PPy and RGO, $\mathrm{Nb}_{6} /$ PPy-RGO-X $(X=0.125,0.25,0.375)$ display the flower-like methodology. To deeply understand the formation of flower-like methodology, the controlled experiments including solvothermal reaction temperatures and the amount of $\mathrm{Py}$ have been respectively conducted using $\mathrm{Nb}_{6} / \mathrm{PPy}-\mathrm{RGO}-0.25$ as a representative. As shown in Figures S2 and S3, the samples probably agglomerated when changing the conditions of $160^{\circ} \mathrm{C}$ or Py $(130 \mu \mathrm{L})$. However, the lower amount of Py, with $90 \mu \mathrm{L}$, or higher temperature of $190^{\circ} \mathrm{C}$ may reduce the surface area and could not form morphology of flowers for $\mathrm{Nb}_{6} / \mathrm{PPy}-\mathrm{RGO}-0.25$. These results demonstrate that the flower-like morphology for $\mathrm{Nb}_{6} / \mathrm{PPy}-\mathrm{RGO}-0.25$ largely depends on the temperature and the amounts of $\mathrm{Py}$ in the reaction. The corresponding EDS elemental mapping of $\mathrm{Nb}_{6} /$ PPy-RGO- 0.25 indicated the elements of $\mathrm{C}, \mathrm{N}, \mathrm{O}, \mathrm{K}$ and $\mathrm{Nb}$ were uniformly distributed throughout the whole composite (Figure 5E).

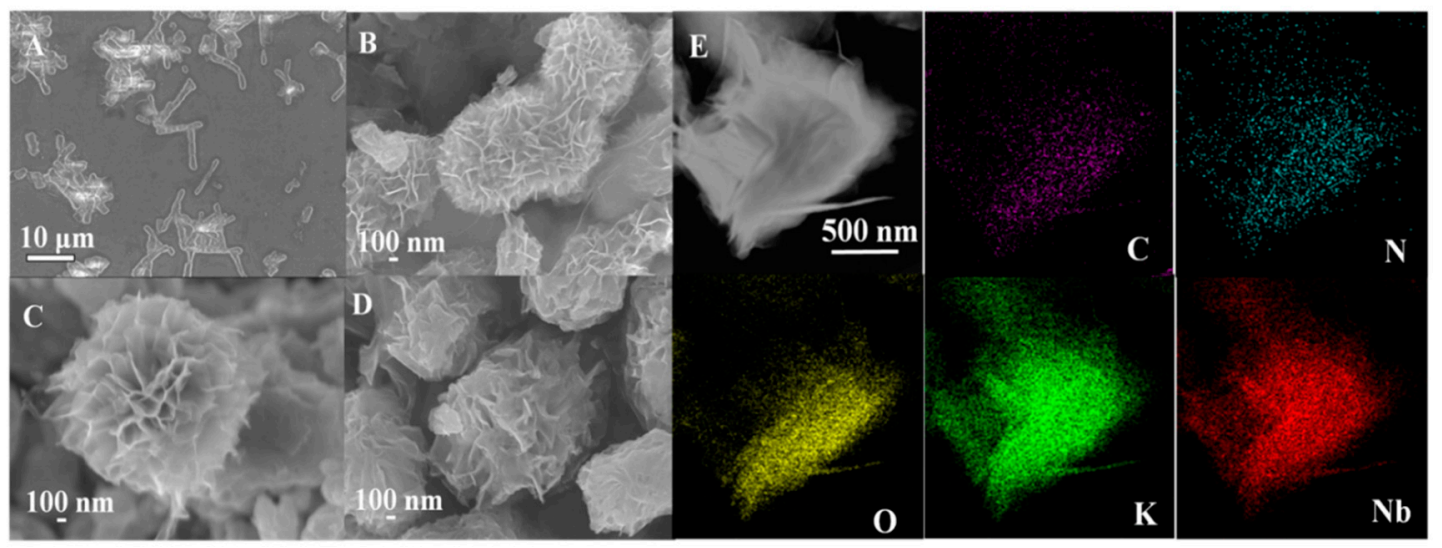

Figure 5. Scanning electron microscopy (SEM) images for: (A) $\mathrm{Nb}_{6}$; (B) $\mathrm{Nb}_{6} / \mathrm{PPy}-\mathrm{RGO}-0.125$; (C) $\mathrm{Nb}_{6} / \mathrm{PPy}-\mathrm{RGO}-0.25$; (D) $\mathrm{Nb}_{6} / \mathrm{PPy}$-RGO-0.375. (E) Transmission electron microscopy (TEM) images and the element maps of $\mathrm{Nb}_{6} / \mathrm{PPy}-\mathrm{RGO}-0.25$.

\subsection{Photochemistry and Electrochemistry}

The UV-Vis diffuse reflectance spectra of $\mathrm{Nb}_{6} / \mathrm{PPy}-\mathrm{RGO}$ composites were recorded at room temperature to discuss their optical properties, together with $\mathrm{Nb}_{6}$ for comparison. As shown in Figure 6, $\mathrm{Nb}_{6} / \mathrm{PPy}-\mathrm{RGO}$ composites exhibit broad absorptions in the range of 200-340 nm. Compared with the absorption of $\mathrm{Nb}_{6}(200-315 \mathrm{~nm})$, the light absorption of $\mathrm{Nb}_{6} / \mathrm{PPy}-\mathrm{RGO}$ samples was obviously widened, which is related to the introduction of PPy and RGO. Due to the zero band gap for RGO, with the increasing amounts of $\mathrm{Nb}_{6}$, the absorbance intensity for $\mathrm{Nb}_{6} / \mathrm{PPy}-\mathrm{RGO}$ composites become weaker (Figure 6a). Simultaneously, the color becomes lighter and the ability to capture light is decreased (Figure S4), hinting that the enhanced absorption is mainly attributed to the introduction of RGO. The band-gap values of $\mathrm{Nb}_{6}$ and $\mathrm{Nb}_{6} / \mathrm{PPy}$-RGO composites (from 0.125 to 0.375 ) obtained by the Kubelka-Munk function via the UV-Vis diffuse reflectance are 4.14, 3.66, 3.71, and $3.76 \mathrm{eV}$, respectively, indicating the semiconductor characters of $\mathrm{Nb}_{6} / \mathrm{PPy}$ - $\mathrm{RGO}$ composites (Figure $6 \mathrm{~b}$ ). Compared to the band gap value of $\mathrm{Nb}_{6}$, those of $\mathrm{Nb}_{6} / \mathrm{PPy}-\mathrm{RGO}$ composites are obviously narrowed through the incorporation of RGO and PPy.

Furthermore, the potentials of conduction band (CB) of $\mathrm{Nb}_{6} / \mathrm{PPy}-\mathrm{RGO}$ composites could be obtained from electrochemical Mott-Schottky plots (Figure S5). The plots of $\mathrm{C}^{-2}$ vs. potential exhibited positive slopes, indicating that we should consider the composites as typical n-type semiconductors [57]. The flat band position of $\mathrm{Nb}_{6} / \mathrm{PPy}-\mathrm{RGO}$ composites determined from the intersection of the Mott-Schottky plot and $\mathrm{X}$ axis are approximately $-1.01 \mathrm{~V}\left(\mathrm{Nb}_{6} / \mathrm{PPy}-\mathrm{RGO}-0.125\right)$, $-1.34 \mathrm{~V}\left(\mathrm{Nb}_{6} / \mathrm{PPy}-\mathrm{RGO}-0.25\right)$ and $-1.23 \mathrm{~V}\left(\mathrm{Nb}_{6} / \mathrm{PPy}-\mathrm{RGO}-0.375\right)$ (vs. NHE, NHE = Normal hydrogen electrode). These results imply that the potentials of $\mathrm{CB}$ of $\mathrm{Nb}_{6} / \mathrm{PPy}-\mathrm{RGO}$ composites are more negative 
than the redox potential of $\mathrm{H}^{+} / \mathrm{H}_{2}(-0.41 \mathrm{~V}$ vs. NHE, $\mathrm{pH}=7)$ [63], indicating the title composites should be used as photocatalysts for hydrogen evolution via water splitting.

As shown in Figure S6, compared with other composites, the $\mathrm{Nb}_{6} / \mathrm{PPy}$-RGO- 0.25 composite displays the weakest PL intensity at $378 \mathrm{~nm}$, and the amount of pyrrole and the solvothermal temperature had little effect on the separation of photo-excited charge and holes, indicative of the lowest combination of electron-hole pairs. Because $\mathrm{K}_{7} \mathrm{HNb}_{6} \mathrm{O}_{19}$ has good water solubility, electrochemical measurement cannot be performed under the same conditions. As shown in Figure 7a, the highest photocurrent response of $\mathrm{Nb}_{6} / \mathrm{PPy}-\mathrm{RGO}-0.25$ shows better separation ability and lower recombination of photogenerated electron-hole pairs [42]. As depicted in Figure $7 \mathrm{~b}$, the smallest radius of $\mathrm{Nb}_{6} / \mathrm{PPy}-\mathrm{RGO}-0.25$ indicates lower charge transfer resistance. This result confirms that more photo-generated charge carriers can be separated by constructing $\mathrm{Nb}_{6} / \mathrm{PPy}-\mathrm{RGO}-0.25$, which is consistent with the result of PL analysis and photocurrent response.
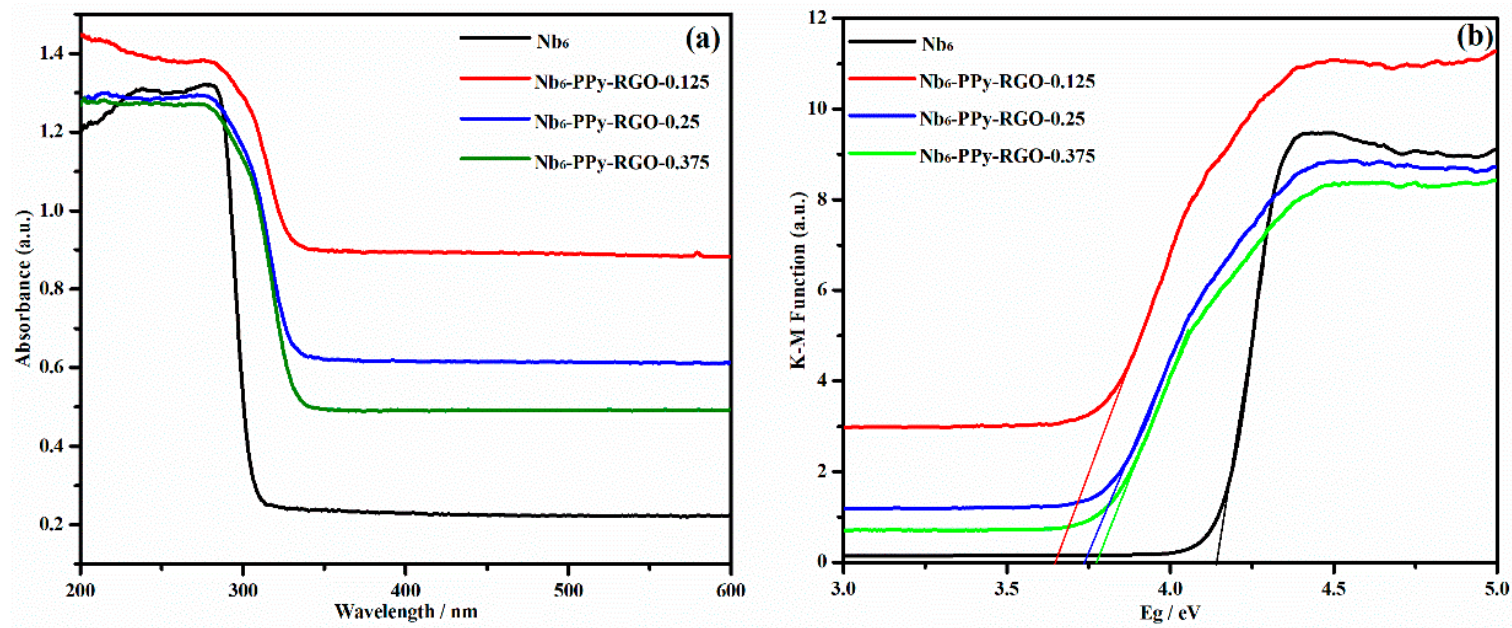

Figure 6. (a) UV-vis diffuses reflectance spectra of $\mathrm{Nb}_{6}$ and $\mathrm{Nb}_{6} / \mathrm{PPy}$-RGO composites; (b) KubelkaMunk function-calculated band gap of $\mathrm{Nb}_{6}$ and $\mathrm{Nb}_{6} / \mathrm{PPy}-\mathrm{RGO}$ composites.
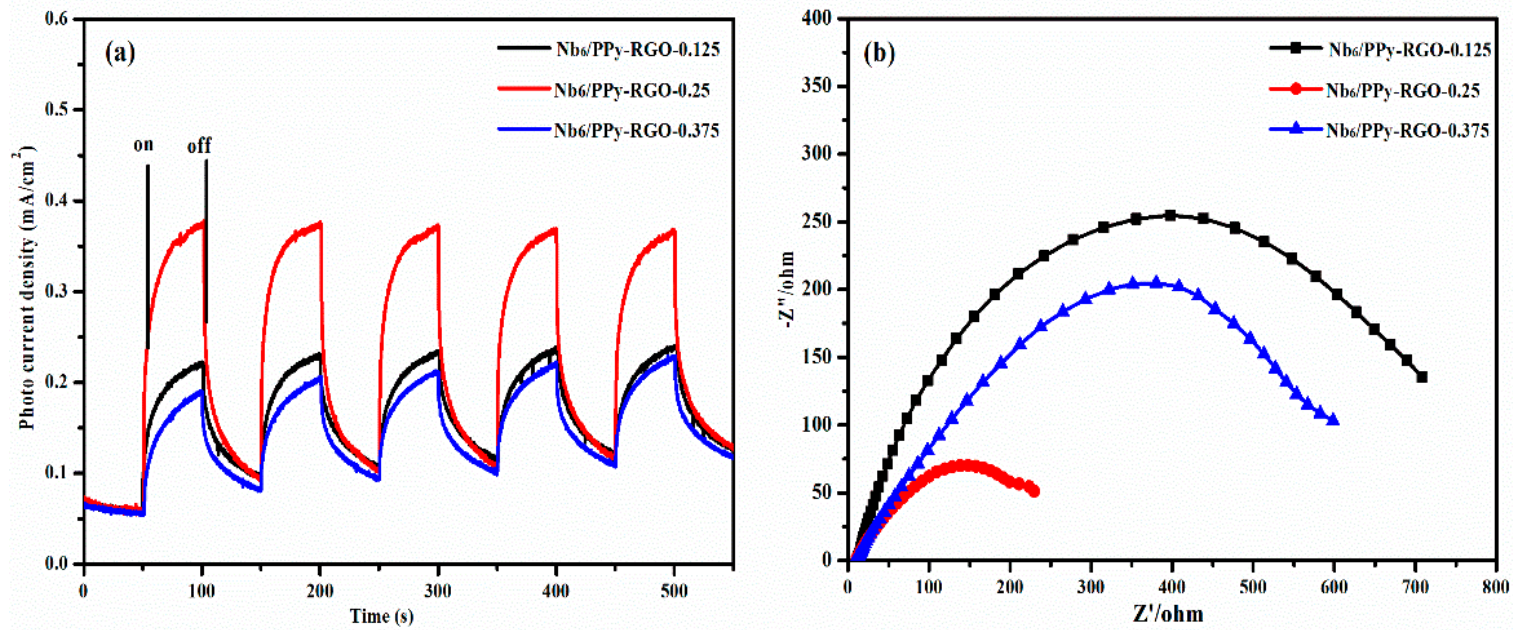

Figure 7. (a) Transient photocurrent response and (b) electrochemical impedance spectroscopy (EIS) plots of $\mathrm{Nb}_{6} / \mathrm{PPy}-\mathrm{RGO}-0.125, \mathrm{Nb}_{6} / \mathrm{PPy}-\mathrm{RGO}-0.25$ and $\mathrm{Nb}_{6} / \mathrm{PPy}-\mathrm{RGO}-0.375$.

\subsection{Photocatalytic Hydrogen Evolution}

Photocatalytic activity of $\mathrm{Nb}_{6} / \mathrm{PPy}-\mathrm{RGO}$ composites for hydrogen evolution via water splitting was evaluated in aqueous solution with methanol $\left(\mathrm{CH}_{3} \mathrm{OH}\right)$ as a sacrificial electron donor. As shown in Figure 8 , the $\mathrm{H}_{2}$ production for $\mathrm{Nb}_{6} / \mathrm{PPy}-\mathrm{RGO}$ composites was $351.5\left(\mathrm{Nb}_{6} / \mathrm{PPy}-\mathrm{RGO}-0.125\right)$, $1038\left(\mathrm{Nb}_{6} /\right.$ PPy-RGO-0.25) and $690.5 \mu \mathrm{mol} \mathrm{g}^{-1}\left(\mathrm{Nb}_{6} /\right.$ PPy-RGO-0.375) in $5 \mathrm{~h}$, respectively. Under the 
same conditions, the $\mathrm{H}_{2}$ production was $25 \mu \mathrm{mol} \mathrm{g}{ }^{-1}$ for the $\mathrm{Nb}_{6}$ catalyst. Apparently, the composites exhibit higher photocatalytic activity by introduction of PPy and RGO. Compared with the other two composites, $\mathrm{Nb}_{6} / \mathrm{PPy}-\mathrm{RGO}-0.125$ and $\mathrm{Nb}_{6} / \mathrm{PPy}-\mathrm{RGO}-0.375, \mathrm{Nb}_{6} / \mathrm{PPy}-\mathrm{RGO}-0.25$ exhibits better photocatalytic efficiency and the turnover frequency (TOF) value reaches $830.4 \times 10^{-3} \mathrm{~h}^{-1}$ (Table 2). These results agree well with EIS and photo-current measurements.

Turnover frequency (TOF) was based on $\mathrm{Nb}_{6}$, which has been widely used to evaluate the property of catalysts, especially for POM-based catalysts. The details are as follows:

$$
\mathrm{TOF}=\frac{n_{\left(\mathrm{H}_{2}\right)} / \mathrm{h}}{n_{\left(\mathrm{Nb}_{6}\right)}}
$$

Taking $\mathrm{Nb}_{6} /$ PPy-RGO-0.25 as an example:

$$
\mathrm{TOF}_{\left(\mathrm{Nb}_{6} / \mathrm{PPy}-\mathrm{RGO}-0.25\right)}=\frac{n_{\left(\mathrm{H}_{2}\right)} / \mathrm{h}}{n_{\left(\mathrm{N} b_{6}\right)}}=\frac{1038 \times 10^{-6} \mathrm{~mol} / 5 \mathrm{~h}}{0.25 \times 10^{-3} \mathrm{~mol}}=830.4 \times 10^{-3} \mathrm{~h}^{-1}
$$

Table 2. The turnover frequency (TOF) values of $\mathrm{Nb}_{6}$ and $\mathrm{Nb}_{6} / \mathrm{PPy}-\mathrm{RGO}$ composites.

\begin{tabular}{ccccc}
\hline Samples & $\mathbf{N b}_{\mathbf{6}}$ & $\mathbf{N b}_{\mathbf{6}} /$ PPy-RGO-0.125 & $\mathbf{N b}_{\mathbf{6}} /$ PPy-RGO-0.25 & $\mathbf{N b}_{\mathbf{6}} /$ PPy-RGO-0.375 \\
\hline TOF $\left(\mathrm{h}^{-1}\right)$ & $137 \times 10^{-3}$ & $562.6 \times 10^{-3}$ & $830.4 \times 10^{-3}$ & $368 \times 10^{-3}$ \\
\hline
\end{tabular}

From the above table, the sample $\mathrm{Nb}_{6} / \mathrm{PPy}-\mathrm{RGO}-0.25$ showed the better photocatalytic activity.

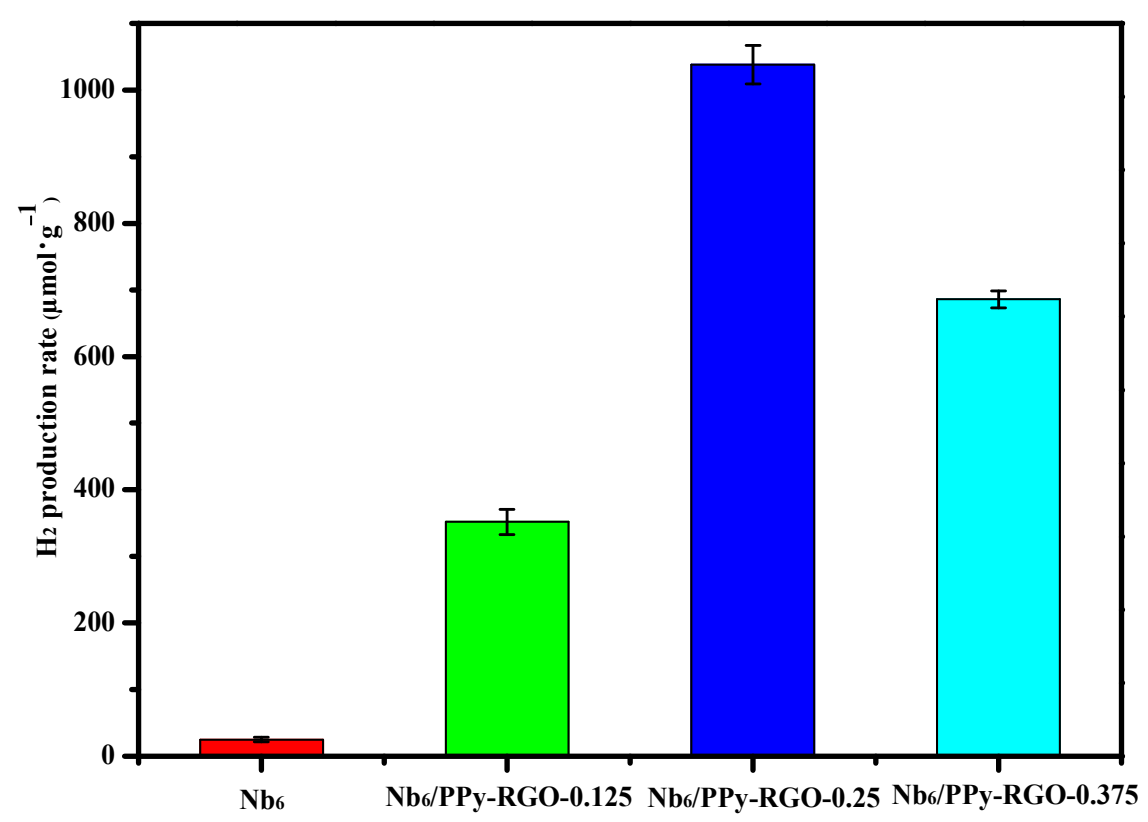

Figure 8. Hydrogen evolution of $\mathrm{Nb}_{6}$ and $\mathrm{Nb}_{6} / \mathrm{PPy}-\mathrm{RGO}$ composites in aqueous solution with $\mathrm{MeOH} 20 \%$.

The photocatalytic system has also been optimized by changing the amount or species of sacrificial electron donors by using the optimal as $\mathrm{Nb}_{6} / \mathrm{PPy}-\mathrm{RGO}-0.25$ photocatalyst. As shown in Figure S7a, when the concentration of $\mathrm{CH}_{3} \mathrm{OH}$ increased from 0 to $20 \%$ (v:v), the hydrogen evolution increased from 0 to $1038 \mu \mathrm{mol} \mathrm{g}^{-1}$, but decreased to 274 and $94 \mu \mathrm{mol} \mathrm{g}{ }^{-1}$ with higher concentrations of $25 \%$ (v:v) and 30\% (v:v), respectively. These results imply that the amount of $\mathrm{CH}_{3} \mathrm{OH}$ played an important role in photocatalytic hydrogen evolution. The more sacrificial electron donors may react with holes of photocatalyst to release more photo-excited electrons to produce more hydrogen. However, with an excess of $\mathrm{CH}_{3} \mathrm{OH}$, it should also decrease the concentrations of substrate, leading to lower 
photocatalytic efficiency. Furthermore, the species of sacrificial electron donor was optimized by controlling the ratio of sacrificial agent $/ \mathrm{H}_{2} \mathrm{O}(v: v=10: 40)$ (Figure S7b). The title photocatalyst exhibited the optimal $\mathrm{H}_{2}$ production of $1038 \mu \mathrm{mol} \mathrm{g}^{-1}$ with $\mathrm{CH}_{3} \mathrm{OH}$ as the sacrificial agent, but varied in the range of $249.5-834 \mu \mathrm{mol} \mathrm{g}^{-1}$ with other sacrificial agents. As shown in Figure S8, the best sample, $\mathrm{Nb}_{6} / \mathrm{PPy}-\mathrm{RGO}-0.25$, exhibits the highest photocatalytic $\mathrm{H}_{2}$ production, indicating the optimal reaction conditions with pyrrole dosage of $110 \mu \mathrm{L}$ and reaction temperature of $180^{\circ} \mathrm{C}$.

In order to prove the reusability of $\mathrm{Nb}_{6} / \mathrm{PPy}-\mathrm{RGO}-0.25$, the recycling experiment was carried out (Figure 9). There was no noticeable deactivation observed for the catalyst and the yields of $\mathrm{H}_{2}$ evolution for the four recycling experiments all remained at $1000 \mu \mathrm{mol} \mathrm{g}^{-1}$ in $5 \mathrm{~h}$. In addition, the XRD pattern (Figure S9), Raman spectra (Figure S10) and SEM image (Figure S11) of the recovered catalysts were alike to those of the as-prepared sample, further demonstrating the recyclability and stability of $\mathrm{Nb}_{6} / \mathrm{PPy}-\mathrm{RGO}-0.25$ in the photocatalysis reaction.

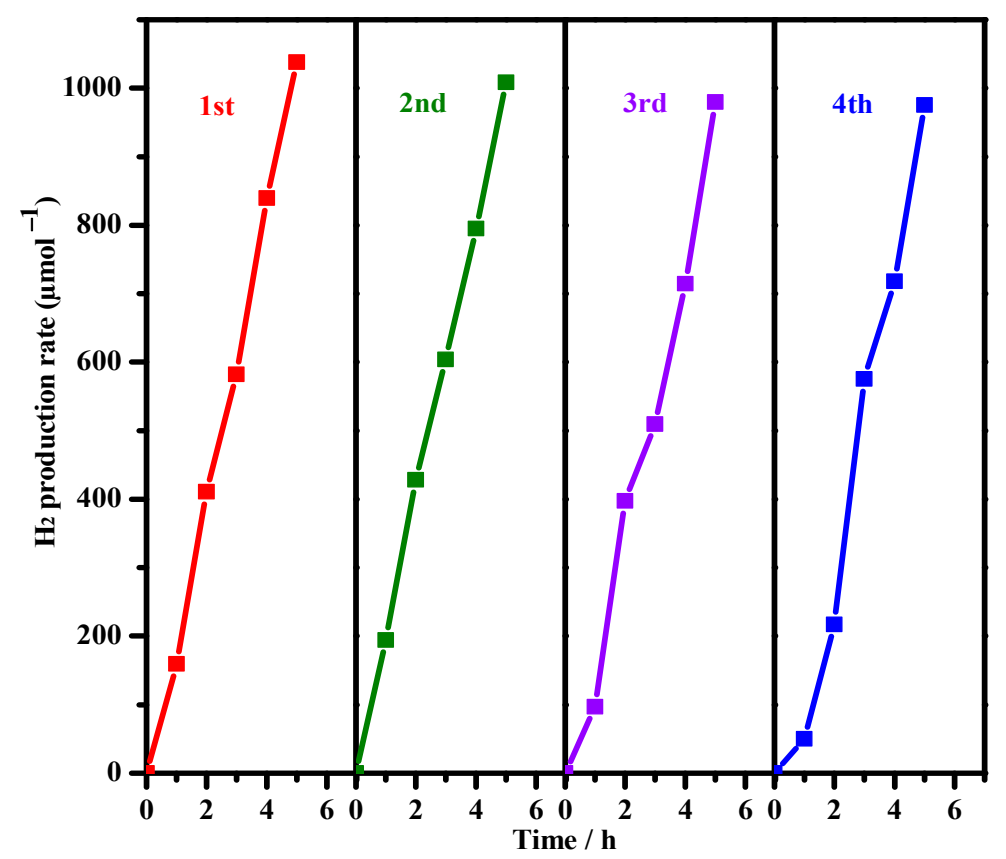

Figure 9. Changes in photocatalytic performance of $\mathrm{Nb}_{6} / \mathrm{PPy}-\mathrm{RGO}-0.25$ during the recycled uses.

\subsection{Proposed Photocatalytic Mechanism}

According to the Mott-Schottky plot shown in Figure S5, the conduction band minimum (CBM) of the composites could be estimated to explain the enhanced photocatalytic activity mechanism, which is about $-1.34 \mathrm{eV}$ for the sample $\mathrm{Nb}_{6} / \mathrm{PPy}-\mathrm{RGO}-0.25$ possessing the best $\mathrm{H}_{2}$ evolution performance. Meanwhile, valence band maximum (VBM) potential of $\mathrm{Nb}_{6} /$ PPy-RGO- 0.25 can be determined based on the formula $E_{\mathrm{VBM}}=E_{\mathrm{CBM}}+E_{\mathrm{g}}$, which is about $2.37 \mathrm{eV}$ [64]. As displayed in Figure 10, the pure $\mathrm{Nb}_{6}$ exhibits negligible photocatalytic activity, which may be due to the fast recombination of electrons and holes. Higher photocatalytic efficiency can be achieved for $\mathrm{Nb}_{6} / \mathrm{PPy}-\mathrm{RGO}$ composites by the modification with PPy and RGO. It has been reported that conductive polymers can be used as photocatalysts for $\mathrm{H}_{2}$ production from water splitting [65]. However, in such $\mathrm{Nb}_{6} / \mathrm{PPy}-\mathrm{RGO}-0.25$ composites, pure PPy and RGO cannot exhibit photocatalytic activity due to their combination of electrons and holes. On the other hand, they can prolong the lifetime of charge carriers to promote the separation efficiency of electron-hole pairs in $\mathrm{Nb}_{6} / \mathrm{PPy}-\mathrm{RGO}-0.25$ composites due to their excellent $\pi$ conjugated chain structure and electrical conductivity. In addition, RGO can also serve as active sites to produce $\mathrm{H}_{2}$, avoiding the use of noble metals, while PPy acted as conductive polymers, promoting the transfer of the electrons $[52,53,66-69]$. In particular, the $\pi-\pi$ interaction between RGO and PPy further strengthens the electrical conductivity. Based on the above results, a probable photocatalytic 
mechanism for composites could be proposed as follows: under light irradiation, the electrons in the valence band (VB) of $\mathrm{Nb}_{6} / \mathrm{PPy}-\mathrm{RGO}-0.25$ can be excited to the $\mathrm{CB}$, causing holes in the VB. On one hand, the holes in the VB could be quenched by accepting electrons from $\mathrm{CH}_{3} \mathrm{OH}$. On the other hand, the photoelectron in the $\mathrm{CB}$ of $\mathrm{Nb}_{6} / \mathrm{PPy}-\mathrm{RGO}-0.25$ could be transferred to RGO through the bridge of PPy. Acting as photoactive sites, the RGO accepting electrons would react with $\mathrm{H}_{2} \mathrm{O}$ to produce $\mathrm{H}_{2}$.

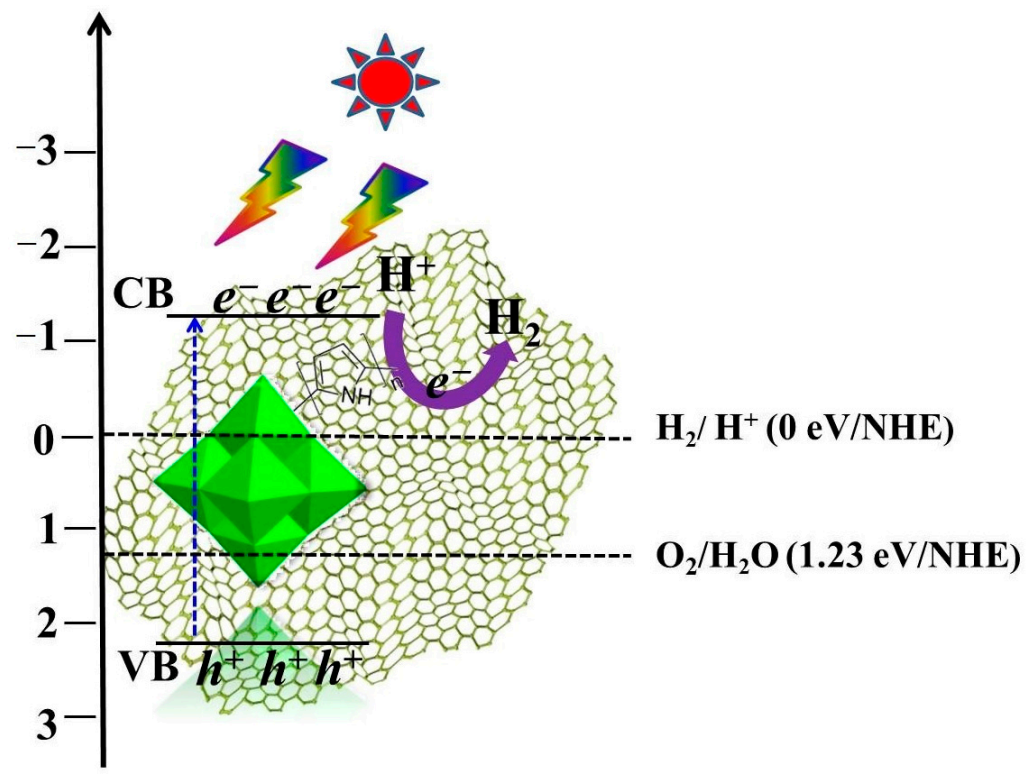

Figure 10. The proposed photocatalytic hydrogen production mechanism of $\mathrm{Nb}_{6} / \mathrm{PPy}-\mathrm{RGO}-0.25$ (NHE = normal hydrogen electrode).

\section{Conclusions}

In summary, a series of unprecedented polyoxoniobate-graphene nanocomposites, $\mathrm{Nb}_{6} / \mathrm{PPy}-\mathrm{RGO}$, have been successfully synthesized through a simple one-step solvothermal method. This is the first example of polyoxoniobate-graphene nanocomposites for photocatalytic $\mathrm{H}_{2}$ production. This work presents a new idea for the design and synthesis of high-performance polyoxometalates-graphene photocatalysts in photocatalytic $\mathrm{H}_{2}$ production. $\mathrm{Nb}_{6} / \mathrm{PPy}-\mathrm{RGO}$ was optimized by adjusting the amount of $\mathrm{Nb}_{6}$, volume of pyrrole and temperature, displaying superb photocatalytic $\mathrm{H}_{2}$ production of $1038 \mu \mathrm{mol} \mathrm{g}^{-1}$ in $5 \mathrm{~h}$ without a co-catalyst, almost 43 times more than pure $\mathrm{Nb}_{6}$, in which the collaborations among $\mathrm{Nb}_{6}$, PPy and RGO play vital roles in such a photocatalytic system. In further work, we will focus on studying more fascinating polyoxoniobate-graphene nanocomposites with new interesting properties.

Supplementary Materials: The following are available online at http://www.mdpi.com/2079-4991/10/12/2449/ s1, Figure S1: X-ray diffraction (XRD) patterns for series of concentration of pyrrole and temperature and the corresponding starting materials. Figure S2: SEM images for (a) $\mathrm{Nb}_{6}-\mathrm{RGO}$; (b) $\mathrm{Nb}_{6} / \mathrm{PPy}-\mathrm{RGO}-90 \mu \mathrm{L}$; (c) $\mathrm{Nb}_{6} / \mathrm{PPy}-\mathrm{RGO}-110 \mu \mathrm{L}$; (d) Nb 6 PPy-RGO-130 $\mu \mathrm{L}$ (SEM = scanning electron microscopy, $\mathrm{Nb}_{6}=\mathrm{K}_{7} \mathrm{HNb}_{6} \mathrm{O}_{19}$, $\mathrm{RGO}=$ reduced graphene oxide, PPy $=$ polypyrrole). Figure S3: SEM images for $(\mathbf{a}) \mathrm{Nb}_{6} / \mathrm{PPy}-\mathrm{RGO}-160$ ${ }^{\circ} \mathrm{C}$; (b) $\mathrm{Nb}_{6} / \mathrm{PPy}-\mathrm{RGO}-180{ }^{\circ} \mathrm{C}$; (c) $\mathrm{Nb}_{6} / \mathrm{PPy}-\mathrm{RGO}-190{ }^{\circ} \mathrm{C}$. Figure S4: The color change of samples. Figure S5: Mott-Schottky plots of (a) Nb $/$ PPy-RGO-0.125; (b) Nb $/$ PPy-RGO-0.25; (c) Nb $/$ PPy-RGO-0.375, in $0.2 \mathrm{M} \mathrm{Na}_{2} \mathrm{SO}_{4}$ aqueous solution with $\mathrm{pH}=7$. Figure S6: Photoluminescence (PL) spectra recorded at room temperature in the range of 325-450 $\mathrm{nm}$ with an excitation wavelength of $378 \mathrm{~nm}$ for adjust (a) molar ratio of $\mathrm{Nb}_{6}$; (b) volume of pyrrole; (c) temperature. Figure S7: (a) Rate of $\mathrm{H}_{2}$ evolution as a function of $\mathrm{CH}_{3} \mathrm{OH}$ concentration, (b) Rate of $\mathrm{H}_{2}$ evolution as a function of type of sacrificial agents. Figure S8: Photocatalytic hydrogen production in concentration of pyrrole (a) and temperature (b) in aqueous solution with $\mathrm{MeOH} 20 \%$. Figure S9: XRD patterns of $\mathrm{Nb}_{6} / \mathrm{PPy}^{\mathrm{R}} \mathrm{RGO}-0.25$ before and after photocatalytic $\mathrm{H}_{2}$ evolution reaction. Figure S10: Raman spectra of $\mathrm{Nb}_{6} / \mathrm{PPy}-\mathrm{RGO}-0.25$ before and after photocatalytic $\mathrm{H}_{2}$ evolution reaction. Figure S11: SEM images for (a) $\mathrm{Nb}_{6} / \mathrm{PPy}-\mathrm{RGO}-0.25$ and (b) that after the recycle of photocatalytic hydrogen evaluation. 
Author Contributions: Conceptualization, S.H. and D.D.; investigation, S.H., W.L., H.L. and M.Z.; writing一original draft preparation, S.H. and L.L.; writing-review and editing, Y.B., D.D. and L.L.; supervision, Y.B. and D.D.; funding acquisition, Y.B. and J.P. All authors have read and agreed to the published version of the manuscript.

Funding: The author thanks the support of the National Natural Science Foundation of China (No. 21971055), the Foundation of the Education Department of Henan Province of China (No. 21A150011 and No. 19B150001), the Postdoctoral Science Foundation of China (No. 2019M652518), and the Postdoctoral Scientific Research Foundation of Henan Province.

Conflicts of Interest: The authors declare no conflict of interest.

\section{References}

1. Li, H.; Sun, Y.; Yuan, Z.Y.; Zhu, Y.P.; Ma, T.Y. Titanium Phosphonate Based Metal-Organic Frameworks with Hierarchical Porosity for Enhanced Photocatalytic Hydrogen Evolution. Angew. Chem. Int. Ed. 2018, 57, 3222-3227. [CrossRef] [PubMed]

2. Li, X.; Yu, J.G.; Wageh, S.; Al-Ghamdi, A.A.; Xie, J. Graphene in Photocatalysis: A Review. Small 2016, 12, 6640-6696. [CrossRef]

3. Zhang, G.; Wang, G.; Liu, Y.; Liu, H.; Qu, J.; Li, J. Highly Active and Stable Catalysts of Phytic Acid-Derivative Transition Metal Phosphides for Full Water Splitting. J. Am. Chem. Soc. 2016, 138, 14686-14693. [CrossRef] [PubMed]

4. Gao, M.M.; Zhu, L.L.; Ong, W.L.; Wang, L.; Ho, G.W. Structural design of $\mathrm{TiO}_{2}$-based photocatalyst for $\mathrm{H}_{2}$ production and degradation applications. Catal. Sci. Technol. 2015, 5, 4703-4726. [CrossRef]

5. Fujishima, A.; Honda, K. Electrochemical Photolysis of Water at a Semiconductor Electrode. Nature 1972, 238, 37-38. [CrossRef]

6. Li, L.; Zhu, S.; Hao, R.; Wang, J.J.; Yang, E.C.; Zhao, X.J. Amino group promoted photocatalytic hydrogen evolution activity observed in two copper(ii)-based layered complexes. Dalton Trans. 2018, 47, 12726-12733. [CrossRef]

7. Zhao, X.X.; Feng, J.R.; Liu, J.W.; Lu, J.; Shi, W.; Yang, G.M.; Wang, G.C.; Feng, P.Y.; Cheng, P. Metal-Organic Framework-Derived ZnO/ZnS Heteronanostructures for Efficient Visible-Light-Driven Photocatalytic Hydrogen Production. Adv. Sci. 2018, 5, 1700590-1700598. [CrossRef]

8. Afroz, K.; Moniruddin, M.; Bakranov, N.; Kudaibergenov, S.; Nuraje, N. A heterojunction strategy to improve the visible light sensitive water splitting performance of photocatalytic materials. J. Mater. Chem. A 2018, 6, 21696-21718. [CrossRef]

9. Stroyuk, O.; Raevskaya, A.; Gaponik, N. Solar light harvesting with multinary metal chalcogenide nanocrystals. Chem. Soc. Rev. 2018, 47, 5354-5422. [CrossRef]

10. Kumar, P.; Boukherroub, R.; Shankar, K. Sunlight-driven water-splitting using two-dimensional carbon based semiconductors. J. Mater. Chem. A 2018, 6, 12876-12931. [CrossRef]

11. Li, S.J.; Liu, S.M.; Liu, S.X.; Liu, Y.W.; Tang, Q.; Shi, Z.; Ou yang, S.X.; Ye, J.H. $\left\{\mathrm{Ta}_{12}\right\} /\left\{\mathrm{Ta}_{16}\right\}$ Cluster-Containing Polytantalotungstates with Remarkable Photocatalytic $\mathrm{H}_{2}$ Evolution Activity. J. Am. Chem. Soc. 2012, 138, 19716-19721. [CrossRef] [PubMed]

12. Qin, J.S.; Du, D.Y.; Guan, W.; Bo, X.J.; Li, Y.F.; Guo, L.P.; Su, Z.M.; Wang, Y.Y.; Lan, Y.Q.; Zhou, H.C. Ultrastable Polymolybdate-Based Metal-Organic Frameworks as Highly Active Electrocatalysts for Hydrogen Generation from Water. J. Am. Chem. Soc. 2015, 137, 7169-7177. [CrossRef] [PubMed]

13. Yu, L.; Ding, Y.; Zheng, M. Polyoxometalate-based manganese clusters as catalysts for efficient photocatalytic and electrochemical water oxidation. Appl. Catal. B Environ. 2017, 209, 45-52. [CrossRef]

14. Geletii, Y.V.; Botar, B.; Kögerler, P.; Hillesheim, D.A.; Musaev, D.G.; Hill, C.L. An All-Inorganic, Stable, and Highly Active Tetraruthenium Homogeneous Catalyst for Water Oxidation. Angew. Chem. Int. Ed. 2008, 47, 3896-3899. [CrossRef]

15. Du, X.Q.; Zhao, J.L.; Mi, J.Q.; Ding, Y.; Zhou, P.P.; Ma, B.C.; Zhao, J.W.; Song, J. Efficient photocatalytic $\mathrm{H}_{2}$ evolution catalyzed by an unprecedented robust molecular semiconductor $\left\{\mathrm{Fe}_{11}\right\}$ nanocluster without cocatalysts at neutral conditions. Nano Energy 2015, 16, 247-255. [CrossRef]

16. Chen, L.; Chen, W.L.; Wang, X.L.; Li, Y.G.; Su, Z.M.; Wang, E.B. Polyoxometalates in dye-sensitized solar cells. Chem. Soc. Rev. 2019, 48, 260-284. [CrossRef]

17. Troupis, A.; Hiskia, A.; Papaconstantinou, E. Photocatalytic Reduction and Recovery of Copper by Polyoxometalates. Environ. Sci. Technol. 2002, 36, 5355-5362. [CrossRef] 
18. Kornarakis, I.; Lykakis, I.N.; Vordos, N.; Armatas, G.S. Efficient visible-light photocatalytic activity by band alignment in mesoporous ternary polyoxometalate- $\mathrm{Ag}_{2} \mathrm{~S}-\mathrm{CdS}$ semiconductors. Nanoscale 2014, 6, 8694-8703. [CrossRef]

19. Hu, B.; Wang, P.F.; Hou, J.; Wang, C.; Qian, J.; Zhang, N.N.; Yuan, Q.S. Effects of titanium dioxide (TiO 2$)$ nanoparticles on the photodissolution of particulate organic matter: Insights from fluorescence spectroscopy and environmental implications. Environ. Pollut. 2017, 229, 19-28. [CrossRef]

20. Park, H.; Choi, W. Photocatalytic conversion of benzene to phenol using modified $\mathrm{TiO}_{2}$ and polyoxometalates. Catal. Today 2005, 101, 291-297. [CrossRef]

21. Zhao, S.; Zhao, X. Polyoxometalates-derived metal oxides incorporated into graphitic carbon nitride framework for photocatalytic hydrogen peroxide production under visible light. J. Catal. 2018, 366, 98-106. [CrossRef]

22. Li, K.X.; Yan, L.S.; Zeng, Z.X.; Luo, S.L.; Luo, X.B.; Liu, X.M.; Guo, H.Q.; Guo, Y.H. Fabrication of $\mathrm{H}_{3} \mathrm{PW}_{12} \mathrm{O}_{40}$-doped carbon nitride nanotubes by one-step hydrothermal treatment strategy and their efficient visible-light photocatalytic activity toward representative aqueous persistent organic pollutants degradation. Appl. Catal. B Environ. 2014, 156-157, 141-152. [CrossRef]

23. Gamelas, J.A.F.; Evtuguin, D.V.; Esculcas, A.P. Transition metal substituted polyoxometalates supported on amine-functionalized silica. Transit. Met. Chem. 2007, 32, 1061-1067. [CrossRef]

24. Sajjad, S.; Leghari, S.A.K.; Iqbal, A. Study of Graphene Oxide Structural Features for Catalytic, Antibacterial, Gas Sensing, and Metals Decontamination Environmental Applications. ACS Appl. Mater. Inter. 2017, 9, 43393-43414. [CrossRef] [PubMed]

25. Kamat, P.V. Graphene-Based Nanoassemblies for Energy Conversion. J. Phys. Chem. Lett. 2011, 2, $242-251$. [CrossRef]

26. Zhang, N.; Zhang, Y.H.; Xu, Y.J. Recent progress on graphene-based photocatalysts: Current status and future perspectives. Nanoscale 2012, 4, 5792-5813. [CrossRef]

27. Liu, J.; Zhang, H.C.; Tang, D.; Zhang, X.; Yan, L.K.; Han, Y.Z.; Huang, H.; Liu, Y.; Kang, Z.H. Carbon Quantum Dot/Silver Nanoparticle/Polyoxometalate Composites as Photocatalysts for Overall Water Splitting in Visible Light. Chem CatChem 2014, 6, 2634-2641. [CrossRef]

28. Liu, G.D.; Zhao, X.F.; Zhang, J.; Liu, S.J.; Sha, J.Q. Z-scheme $\mathrm{Ag}_{3} \mathrm{PO}_{4} / \mathrm{POM} / \mathrm{GO}$ heterojunction with enhanced photocatalytic performance for degradation and water splitting. Dalton Trans. 2018, 47, 6225-6232. [CrossRef]

29. Tang, Y.J.; Wang, Y.; Wang, X.L.; Li, S.L.; Huang, W.; Dong, L.Z.; Liu, C.H.; Li, Y.F.; Lan, Y.Q. Molybdenum Disulfide/Nitrogen-Doped Reduced Graphene Oxide Nanocomposite with Enlarged Interlayer Spacing for Electrocatalytic Hydrogen Evolution. Adv. Energy Mater. 2016, 6, 1600116. [CrossRef]

30. Tang, Y.J.; Liu, C.H.; Huang, W.; Wang, X.L.; Dong, L.Z.; Li, S.L.; Lan, Y.Q. Bimetallic Carbides-Based Nanocomposite as Superior Electrocatalyst for Oxygen Evolution Reaction. ACS Appl. Mater. Inter. 2017, 9, 16977-16985. [CrossRef]

31. Iwase, A.; Ng, Y.H.; Yoshimi, I.; Kudo, A.; Amal, R. Reduced Graphene Oxide as a Solid-State Electron Mediator in Z-Scheme Photocatalytic Water Splitting under Visible Light. J. Am. Chem. Soc. 2011, 133, 11054-11057. [CrossRef] [PubMed]

32. Novoselov, K.S.; Geim, A.K.; Morozov, S.V.; Jiang, D.; Zhang, Y.; Dubonos, S.V.; Grigorieva, I.V.; Firsov, A.A. Electric Field Effect in Atomically Thin Carbon Films. Science 2004, 306, 666-669. [CrossRef] [PubMed]

33. Xiang, Q.J.; Yu, J.G.; Jaroniec, M. Graphene-based semiconductor photocatalysts. Chem. Soc. Rev. 2012, 41, 782-796. [CrossRef]

34. Geim, A.K. Graphene: Status and Prospects. Science 2009, 324, 1530-1534. [CrossRef] [PubMed]

35. Wei, T.; Zhang, M.; Wu, P.; Tang, Y.J.; Li, S.L.; Shen, F.C.; Wang, X.L.; Zhou, X.P.; Lan, Y.Q. POM-based metal-organic framework/reduced graphene oxide nanocomposites with hybrid behavior of battery-supercapacitor for superior lithium storage. Nano Energy 2017, 34, 205-214. [CrossRef]

36. Li, H.L.; Gupta, J.; Wang, S.; Zhang, N.; Bubeck, C. Photoreduction of graphene oxide with polyoxometalate clusters and its enhanced saturable absorption. J. Colloid Interface Sci. 2014, 427, 25-28. [CrossRef] [PubMed]

37. Huang, Y.Y.; Xiao, A.X.; Hou, G.H.; Li, H.T.; Guo, T.; Guan, B.O. Photocatalysis in an evanescent field: An in situ approach to studying photocatalytic performance by tracing interfacial refractive index changes and kinetics. J. Mater. Chem. A 2018, 6, 20513-20522. [CrossRef]

38. Zhang, N.; Yang, M.Q.; Liu, S.Q.; Sun, Y.G.; Xu, Y.J. Waltzing with the Versatile Platform of Graphene to Synthesize Composite Photocatalysts. Chem. Rev. 2015, 115, 10307-10377. [CrossRef] 
39. Wang, Z.L.; Tan, H.Q.; Chen, W.L.; Li, Y.G.; Wang, E.B. A copper(ii)-ethylenediamine modified polyoxoniobate with photocatalytic $\mathrm{H}_{2}$ evolution activity under visible light irradiation. Dalton Trans. 2012, 41, 9882-9884. [CrossRef]

40. Shen, J.Q.; Zhang, Y.; Zhang, Z.M.; Li, Y.G.; Gao, Y.Q.; Wang, E.B. Polyoxoniobate-based 3D framework materials with photocatalytic hydrogen evolution activity. Chem. Commun. 2014, 50, 6017-6019. [CrossRef]

41. Geng, Q.H.; Liu, Q.S.; Ma, P.T.; Wang, J.P.; Niu, J.Y. Synthesis crystal structure and photocatalytic properties of an unprecedented arsenic-disubstituted Lindqvist-type peroxopolyoxoniobate ion: $\left\{\mathrm{As}_{2} \mathrm{Nb}_{4}\left(\mathrm{O}_{2}\right)_{4} \mathrm{O}_{14} \mathrm{H}_{1.5}\right\}^{4.5-}$. Dalton Trans. 2014, 43, 9843-9846. [CrossRef] [PubMed]

42. Hu, J.F.; Wang, Y.; Zhang, X.N.; Chi, Y.N.; Yang, S.; Li, J.K.; Hu, C.W. Controllable Assembly of Vanadium-Containing Polyoxoniobate-Based Three-Dimensional Organic-Inorganic Hybrid Compounds and Their Photocatalytic Properties. Inorg. Chem. 2016, 55, 7501-7507. [CrossRef] [PubMed]

43. Niu, J.Y.; Li, F.; Zhao, J.W.; Ma, P.T.; Zhang, D.D.; Bassil, B.; Kortz, U.; Wang, J.P. Tetradecacobalt(II)-Containing 36-Niobate $\left[\mathrm{Co}_{14}(\mathrm{OH})_{16}\left(\mathrm{H}_{2} \mathrm{O}\right)_{8} \mathrm{Nb}_{36} \mathrm{O}_{106}\right]^{20-}$ and Its Photocatalytic $\mathrm{H}_{2}$ Evolution Activity. Chem. Eur. J. 2014, 20, 9852-9857. [CrossRef] [PubMed]

44. Wu, F.; Xie, A.M.; Sun, M.X.; Wang, Y.; Wang, M.Y. Reduced graphene oxide (RGO) modified spongelike polypyrrole (PPy) aerogel for excellent electromagnetic absorption. J. Mater. Chem. A 2015, 3, 14358-14369. [CrossRef]

45. Abaci, U.; Guney, H.Y.; Kadiroglu, U. Morphological and electrochemical properties of PPy, PAni bilayer films and enhanced stability of their electrochromic devices (PPy/PAni-PEDOT, PAni/PPy-PEDOT). Electrochim. Acta 2013, 96, 214-224. [CrossRef]

46. Filowitz, M.; Ho, R.K.C.; Klemperer, W.G.; Shum, W. ${ }^{17} \mathrm{O}$ nuclear magnetic resonance spectroscopy of polyoxometalates. 1. Sensitivity and resolution. Inorg. Chem. 1979, 18, 93-103. [CrossRef]

47. Hummers, W.S.; Offeman, R.E. Preparation of Graphitic Oxide. J. Am. Chem. Soc. 1958, 80, 1339. [CrossRef]

48. Bao, C.L.; Song, L.; Xing, W.Y.; Yuan, B.H.; Wilkie, C.A.; Huang, J.L.; Guo, Y.Q.; Hu, Y. Preparation of graphene by pressurized oxidation and multiplex reduction and its polymer nanocomposites by masterbatch-based melt blending. J. Mater. Chem. 2012, 22, 6088-6096. [CrossRef]

49. Suvina, V.; Krishna, S.M.; Nagaraju, D.H.; Melo, J.S.; Balakrishna, R.G. Polypyrrole-reduced graphene oxide nanocomposite hydrogels: A promising electrode material for the simultaneous detection of multiple heavy metal ions. Mater. Lett. 2018, 232, 209-212. [CrossRef]

50. Yin, Y.; Zhang, H.T.; Huang, P.R.; Xiang, C.L.; Zou, Y.J.; Xu, F.; Sun, L.X. Inducement of nanoscale Cu-BTC on nanocomposite of PPy-rGO and its performance in ammonia sensing. Mater. Res. Bull. 2018, 99, 152-160. [CrossRef]

51. Liu, R.J.; Li, S.W.; Yu, X.L.; Zhang, G.J.; Zhang, S.J.; Yao, J.N.; Keita, B.; Nadjo, L.; Zhi, L.J. Facile Synthesis of Au-Nanoparticle/Polyoxometalate/Graphene Tricomponent Nanohybrids: An Enzyme-Free Electrochemical Biosensor for Hydrogen Peroxide. Small 2012, 8, 1398-1406. [CrossRef] [PubMed]

52. Han, Y.Q.; Zhang, Z.L.; Yang, M.; Li, T.X.; Wang, Y.M.; Cao, A.P.; Chen, Z.X. Facile preparation of reduced graphene oxide/polypyrrole nanocomposites with urchin-like microstructure for wide-potential-window supercapacitors. Electrochim. Acta 2018, 289, 238-247. [CrossRef]

53. Jiang, Y.Z.; Gu, Y.; Nie, G.D.; Chi, M.Q.; Yang, Z.Z.; Wang, C.; Wei, Y.; Lu, X.F. Synthesis of RGO/Cu $8 \mathrm{~S}_{5} / \mathrm{PPy}$ Composite Nanosheets with Enhanced Peroxidase-Like Activity for Sensitive Colorimetric Detection of $\mathrm{H}_{2} \mathrm{O}_{2}$ and Phenol. Part. Part. Syst. Charact. 2017, 3, 1600233-1600240. [CrossRef]

54. Gan, Q.Y.; Shi, W.L.; Xing, Y.J.; Hou, Y.A. Polyoxoniobate/g- $\mathrm{C}_{3} \mathrm{~N}_{4}$ Nanoporous Material with High Adsorption Capacity of Methylene Blue from Aqueous Solution. Front. Chem. 2018, 6, 7-16. [CrossRef]

55. Aureliano, M.; Ohlin, C.A.; Vieira, M.O.; Marques, M.P.M.; Casey, W.H.; Batista de Carvalho, L.A.E. Characterization of decavanadate and decaniobate solutions by Raman spectroscopy. Dalton Trans. 2016, 45, 7391-7399. [CrossRef]

56. Fullmer, L.B.; Malmberg, C.E.; Fast, D.B.; Wills, L.A.; Cheong, P.H.Y.; Dolgos, M.R.; Nyman, M. Aqueous tantalum polyoxometalate reactivity with peroxide. Dalton Trans. 2017, 46, 8486-8493. [CrossRef]

57. Akhavan, O.; Ghaderi, E. Photocatalytic Reduction of Graphene Oxide Nanosheets on $\mathrm{TiO}_{2}$ Thin Film for Photoinactivation of Bacteria in Solar Light Irradiation. J. Phys. Chem. C 2009, 113, 20214-20220. [CrossRef]

58. Ma, J.; He, Y.; Shi, H.; Fan, Y.; Yu, H.; Li, Y.B. Stable graphene oxide-based composite membranes intercalated with montmorillonite nanoplatelets for water purification. J. Mater. Sci. 2019, 54, 2241-2255. [CrossRef] 
59. Zhang, L.B.; Li, X.T.; Wang, X.H.; Han, L.; Liu, R.Y.; Zheng, B.B.; Li, W.T.; Liu, X.L.; Liu, Y.C. Photo-assisted preparation and patterning of large-area reduced graphene oxide- $\mathrm{TiO}_{2}$ conductive thin film. Chem. Commun. 2010, 46, 3499-3501.

60. Liu, Q.Q.; Shen, J.Y.; Yang, X.F.; Zhang, T.R.; Tang, H. 3D reduced graphene oxide aerogel-mediated Z-scheme photocatalytic system for highly efficient solar-driven water oxidation and removal of antibiotics. Appl. Catal. B Environ. 2018, 232, 562-573. [CrossRef]

61. Bai, X.; Du, Y.Y.; Hu, X.Y.; He, Y.D.; He, C.L.; Liu, E.Z.; Fan, J. Synergy removal of Cr (VI) and organic pollutants over RP-MoS $2 /$ rGO photocatalyst. Appl. Catal. B Environ. 2018, 239, 204-213. [CrossRef]

62. Yang, J.; Huang, J.H.; Fan, D.Y.; Chen, S.H. First-principles investigation on the electronic property and bonding configuration of $\mathrm{NbC}(111) / \mathrm{NbN}$ (111) interface. J. Alloys Compd. 2016, 689, 874-884. [CrossRef]

63. Kulkarni, A.K.; Praveen, C.S.; Sethi, Y.A.; Panman, R.P.; Arbuj, S.S.; Naik, S.D.; Ghule, A.V.; Kale, B.B. Nanostructured $\mathrm{N}$-doped orthorhombic $\mathrm{Nb}_{2} \mathrm{O}_{5}$ as an efficient stable photocatalyst for hydrogen generation under visible light. Dalton Trans. 2017, 46, 14859-14868. [CrossRef] [PubMed]

64. Ma, L.F.; Li, F.Y.; Sun, Z.X.; Liu, M.M.; Wang, Y.H.; Xu, L. Synergetic effect of polyoxoniobate and NiS as cocatalysts for enhanced photocatalytic H2 evolution on Cd0.65Zn0.35S. RSC Adv. 2014, 4, 21369-21372. [CrossRef]

65. Li, T.; Wang, K.; Fang, Q.T.; Zhang, Y.; Wang, B.; Li, R.; Lin, Y.Z.; Liu, K.C.; Xie, H.Q.; Li, K. Conductive polymer supported and confined iron phosphide nanocrystals for boosting the photocatalytic hydrogen production of graphitic carbon nitride. J. Mater. Chem. C 2020, 8, 14540-14547. [CrossRef]

66. Zhang, W.Y.; Shen, C.; Lu, G.X.; Ni, Y.R.; Lu, C.H.; Xu, Z.Z. Synthesis of PPy/RGO-based hierarchical material with super-paramagnetic behavior and understanding its robust photo current driven by visible light. Synth. Met. 2018, 241, 17-25. [CrossRef]

67. Yuan, X.J.; Dragoe, D.; Beaunier, P.; Uribe, D.B.; Ramos, L.; Méndez-Medrano, M.G.; Remita, H. Polypyrrole nanostructures modified with monoand bimetallic nanoparticles for photocatalytic $\mathrm{H}_{2}$ generation. J. Mater. Chem. A 2020, 8, 268-277. [CrossRef]

68. Wang, K.L.; Endo-Kimura, M.; Belchi, R.; Zhang, D.; Habert, A.; Bouclé, J.; Ohtani, B.; Kowalska, E.; Herlin-Boime, N. Carbon/Graphene-Modified Titania with Enhanced Photocatalytic Activity under UV and Vis Irradiation. Materials 2019, 12, 4158. [CrossRef]

69. Yuan, X.J.; Floresyona, D.; Aubert, P.H.; Bui, T.T.; Remita, S.; Ghosh, S.; Brisset, F.; Fabrice, G.; Remita, H. Photocatalytic degradation of organic pollutant with polypyrrole nanostructures under UV and visible light. Appl. Catal. B Environ. 2019, 242, 284-292. [CrossRef]

Publisher's Note: MDPI stays neutral with regard to jurisdictional claims in published maps and institutional affiliations.

(C) 2020 by the authors. Licensee MDPI, Basel, Switzerland. This article is an open access article distributed under the terms and conditions of the Creative Commons Attribution (CC BY) license (http://creativecommons.org/licenses/by/4.0/). 